\title{
GAMBARAN ANGKA KENAIKAN BERAT BADAN SAAT MASA PANDEMI COVID-19 PADA MAHASISWA ANGKATAN 2017 FAKULTAS KEDOKTERAN UNIVERSITAS MALAHAYATI
}

\author{
Festy Ladyani Mustofa ${ }^{1}$, Ismalia Husna ${ }^{2}$, Dessy Hermawan ${ }^{3}$, \\ Siti Sarah Langki ${ }^{4}$
}

\author{
${ }^{1}$ Departemen Gizi Medik Fakultas Kedokteran Universitas Malahayati \\ ${ }^{2}$ Departemen Parasitologi Fakultas Kedokteran Universitas Malahayati \\ ${ }^{3}$ Program Studi Keperawatan Fakultas Kedokteran Universitas Malahayati \\ ${ }^{4}$ Program Studi Pendidikan Dokter Fakultas Kedokteran Universitas Malahayati
}

\begin{abstract}
Overview of Body Increase in The Covid-19 Pandemic Period for 2017 Students of The Faculty of Medicine, Malahayati University. Weight gain can occur due to an imbalance between energy consumption and energy expenditure, such as irregular eating patterns, especially when staying at home during the COVID-19 pandemic. The purpose of this study was to describe the number of weight gain during the COVID-19 pandemic in students of class 2017, Faculty of Medicine, Malahayati University in 2020. Methods: This research is a descriptive study using primary and secondary data. The method of data collection is by using a dietary questionnaire that has been tested for validity and reliability, weighing directly and retrieving previous research data. This research was conducted in December 2020 and the samples were students of class 2017 who met the predetermined criteria as many as 44 respondents with total sampling technique. Based on data processing, most of the respondents experienced a weight gain 25 (56.8) with the largest age distribution 21 years 20 (45.5), female sex 27 (61.4), BMI Obesity 214 (15.9) and there were dietary changes during the COVID-19 pandemic 27 (61.4). There was an increase in body weight during the COVID-19 pandemic in students of class 2017 at the Faculty of Medicine, Malahayati University in 2020 with the highest body weight increase of $1 \mathrm{~kg}$.
\end{abstract}

Keywords: Weight, The COVID-19 Pandemic

\begin{abstract}
Abstrak : Gambaran Angka Kenaikan Berat Badan Saat Masa Pandemi Covid-19 Pada Mahasiswa Angkatan 2017 Fakultas Kedokteran Universitas Malahayati. Penambahan berat badan dapat terjadi akibat adanya ketidakseimbangan antara konsumsi energi dengan pengeluaran energi, seperti pola makan tidak teratur terutama saat stay at home masa pandemi COVID-19. Tujuan penelitian ini untuk mengetahui gambaran angka kenaikan berat badan saat masa pandemi COVID-19 pada mahasiswa angkatan 2017 Fakultas Kedokteran Universitas Malahayati tahun 2020. Penelitian ini adalah penelitian jenis deskriptif yang menggunakan data primer dan sekunder. Cara pengambilan datanya dengan menggunakan kuesioner pola makan yang telah diuji validitas dan reliabilitas, menimbang berat badan secara langsung dan mengambil data penelitian sebelumnya. Penelitian ini dilakukan pada bulan Desember tahun 2020 dan Sampelnya adalah mahasiswa angkatan 2017 yang memenuhi kriteria yang telah ditentukan sebanyak 44 responden dengan teknik pengambilan sampel total sampling. Berdasarkan pengolahan data Berat badan sebagian besar responden mengalami kenaikan berat badan $25(56,8)$ dengan distribusi usia terbanyak 21 tahun $20(45,5)$ jenis kelamin perempuan $27(61,4)$, IMT Obesitas $214(15,9)$ dan terdapat perubahan pola makan saat masa pandemi COVID-19 $27(61,4)$. Terdapat kenaikan berat badan saat masa pandemi COVID-19 pada mahasiswa angkatan 2017 Fakultas Kedokteran Universitas Malahayati Tahun 2020 dengan angka kenaikan berat badan terbanyak $1 \mathrm{~kg}$.
\end{abstract}

Kata kunci : Berat Badan, Pandemi COVID-19 


\section{PENDAHULUAN}

Berat badan merupakan parameter antropometri yang tidak stabil. Saat keadaan normal yaitu kebutuhan gizi seimbang dengan konsumsi gizi, berat badan berkembang sesuai dengan perubahan usia. Saat keadaan abnormal, perkembangan berat badan tidak sesuai dengan perubahan usia, perkembangan berat badan bisa lebih cepat atau berkembang lebih lambat dari keadaan normal. Berat badan harus diperiksa secara rutin agar dapat memberikan informasi yang memungkinkan intervensi gizi sebagai pencegahan guna mengatasi kemungkinan penambahan atau penurunan berat badan yang tidak dikehendaki. Evaluasi berat badan melalui gaya hidup dan status berat badan yang terakhir harus selalu dilakukan (Anggraeni, 2012).

Kondisi antara berat badan dengan tinggi badan melebihi standar yang ditentukan adalah kondisi kelebihan berat badan. Sedangkan kondisi kelebihan lemak, baik terlokalisasi pada bagian bagian tertentu maupun di seluruh tubuh merupakan kondisi yang disebut obesitas (Ganong, 2003).

Seluruh dunia pada saat ini sedang mengalami pandemi yang mempunyai dampak cukup besar di semua sektor kehidupan manusia. Coronavirus Disease 2019 atau COVID19 telah ditetapkan oleh World Health Organization (WHO) sebagai sebuah ancaman pandemi. Pengertian pandemi menurut Kamus Besar Bahasa Indonesia (KBBI) (2020) merupakan wabah yang berjangkit serempak di mana-mana atau meliputi geografi yang luas. Kasus COVID-19 pertama terjadi di Wuhan, Tiongkok dan mulai menyebar hampir ke seluruh dunia. Penyebaran COVID-19 sangat cepat dan tidak dapat diprediksi akhir dari pandemi COVID-19 ini (Risnawati, 2020).

Sembilan puluh satu persen dari sampel menyatakan bahwa mereka menghabiskan waktu lebih banyak dirumah sekarang daripada sebelum COVID-19. Dua puluh dua persen dari sampel menyatakan bahwa berat badan mereka bertambah 5-10 pon (2,5 - 5 $\mathrm{kg}$ ). Di antara mereka yang mengalami kenaikan berat badan 5-10 pon (2,5 - 5 $\mathrm{kg}$ ), terdapat persentase yang lebih tinggi secara signifikan dari total sampel yang melaporkan bahwa mereka meningkatkan makan sebagai tanggapan terhadap penglihatan dan penciuman, makan sebagai tanggapan terhadap stres, dan ngemil setelah makan malam dibandingkan dengan mereka yang menyatakan tidak mengubah perilaku tersebut sama sekali (Zachary et al, 2020).

Obesitas jika tidak ditangani dengan baik akan berdampak sangat merugikan bagi kesehatan penderitanya pada masa yang akan datang. Obesitas dapat menurunkan kualitas hidup seseorang dan meningkatkan pengeluaran dana bagi kesehatannya. Hal ini disebabkan karena obesitas adalah awalan dari beberapa penyakit degeneratif yang sangat mematikan seperti: penyakit kardiovaskular, penyakit jantung, stroke, hipertensi, DM, cancer, alzheimer, sleep apnea, hingga tidak jarang ditemukan obesitas sebagai penyebab kematian dini atau kematian usia muda (Hermawan et al, 2020).

\section{METODE}

Desain penelitian ini adalah deskriptif. Populasi yang digunakan adalah Mahasiswa angkatan 2017 Fakultas Kedokteran Universitas Malahayati, sampel yang digunakan sebanyak 44 responden sesuai dengan kriteria inklusi dan eksklusi yang bersedia menjadi responden.

Teknik pengambilan sampel yang digunakan adalah total sampling. Penelitian ini dilakukan di Universitas Malahayati. Data diperoleh dengan menyebarkan kuesioner yang berisi pertanyaan tentang pola makan mahasiswa, menimbang berat badan, dan mengambil data sekunder dari penelitian sebelumnya. Penelitian ini dilaksanakan pada 11 Desember 2020 11 Januari 2020. 
HASIL

Karakteristik berat badan saat pandemi COVID-19 dapat dilihat di tabel 1 sebagai berikut:

Tabel 1. Karakteristik Berat Badan Saat Pandemi COVID-19

\begin{tabular}{ccc}
\hline Berat Badan & $\mathbf{N}$ & $\mathbf{\%}$ \\
\hline Turun & 13 & 29,5 \\
Tetap & 6 & 13,6 \\
Naik & 25 & 56,8 \\
\hline Total & $\mathbf{4 4}$ & $\mathbf{1 0 0}$
\end{tabular}

Berdasarkan tabel 1 diketahui bahwa sebagian besar responden berat badan saat pandemi pada memiliki berat badan paling banyak BB responden penelitian angka kenaikan Naik yaitu sebesar 25 (56,8\%) dan berat badan saat masa pandemi COVID- paling sedikit $(13,6 \%)$ pada peserta 19 pada mahasiswa angkatan 2017 dengan BB Tetap. Karakteristik Fakultas Kedokteran Universitas kenaikan berat badan dalam penelitian Malahayati tahun 2020 menunjukkan ini dapat dilihat pada tabel 2 berikut:

Tabel 2. Data Distribusi Frekuensi Kenaikan Berat Badan

\begin{tabular}{ccc}
\hline Berat Badan $(\mathbf{K g})$ & $\mathbf{N}$ & $\mathbf{\%}$ \\
\hline Naik 1 & 7 & 28,0 \\
Naik 2 & 4 & 16,0 \\
Naik 3 & 2 & 8,0 \\
Naik 4 & 4 & 16,0 \\
Naik 5 & 3 & 12,0 \\
Naik 6 & 2 & 8,0 \\
Naik 7 & 0 & 0,0 \\
Naik 8 & 1 & 4,0 \\
Naik 9 & 1 & 4,0 \\
Naik 10 & 1 & 4,0 \\
\hline Total & $\mathbf{4 4}$ & $\mathbf{1 0 0}$ \\
\hline
\end{tabular}

Berdasarkan tabel 2 diketahui responden memiliki kenaikan berat kenaikan berat badan saat pandemi badan paling banyak yaitu $1 \mathrm{Kg}$ sebesar pada responden penelitian angka $7(28,0 \%)$ responden dan paling sedikit kenaikan berat badan saat masa $1(4,0 \%)$ pada responden dengan pandemi COVID-19 pada mahasiswa Kenaikan Berat Badan $8 \mathrm{Kg}, 9 \mathrm{Kg}$ dan angkatan 2017 Fakultas Kedokteran $10 \mathrm{Kg}$. Karakteristik usia dalam Universitas Malahayati tahun 2020 penelitian ini dapat dilihat pada tabel 3 menunjukkan bahwa sebagian besar berikut:

Tabel 3. Distribusi Frekuensi Karakteristik Usia

\begin{tabular}{ccc}
\hline Usia & N & \% \\
\hline 20 Tahun & 5 & 11,4 \\
21 Tahun & 20 & 45,5 \\
22 Tahun & 13 & 29,5 \\
23 Tahun & 3 & 6,8 \\
24 Tahun & 2 & 4,5 \\
25 Tahun & 1 & 2,3 \\
\hline Jumlah & $\mathbf{4 4}$ & $\mathbf{1 0 0}$
\end{tabular}


Berdasarkan tabel 3 di atas didapatkan bahwa sebagian besar responden penelitian angka kenaikan berat badan saat masa pandemi COVID19 pada mahasiswa angkatan 2017 adalah usia 21 tahun yang terdiri dari
20 peserta yang terdiri dari 20 responden $(45,5 \%)$, responden paling sedikit adalah usia 22 tahun yang terdiri dari 1 responden (2,3\%). Karakteristik jenis kelamin dalam penelitian ini dapat dilihat pada tabel 4 berikut:

Tabel 4. Distribusi Frekuensi Karakteristik Jenis Kelamin

\begin{tabular}{ccc}
\hline Jenis kelamin & Frekuensi & Persentase (\%) \\
\hline Perempuan & 27 & 61,4 \\
Laki-laki & 17 & 38,6 \\
\hline Jumlah & $\mathbf{4 4}$ & $\mathbf{1 0 0}$
\end{tabular}

Berdasarkan tabel 4 dapat kelamin perempuan yaitu sebanyak 27 diketahui bahwa sebagian besar responden $(61,4 \%)$ dan paling sedikit responden penelitian angka kenaikan adalah jenis kelamin laki-laki yaitu berat badan saat masa pandemi COVID- sebanyak 17 peserta (38,3\%). 19 pada mahasiswa angkatan 2017 Karakteristik IMT dalam penelitian ini Fakultas Kedokteran Universitas Malahayati tahun 2020 adalah jenis dapat dilihat pada tabel 5 berikut:

Tabel 5. Distribusi Frekuensi Karakteristik IMT

\begin{tabular}{ccc}
\hline IMT & Frekuensi & Presentase (\%) \\
\hline Normal & 11 & 25,0 \\
Overweight & 7 & 27,3 \\
Obesitas 1 & 12 & 31,8 \\
Obesitas 2 & 14 & 15,9 \\
\hline Jumlah & $\mathbf{4 4}$ & $\mathbf{1 0 0}$ \\
\hline
\end{tabular}

Berdasarkan Tabel 5 di atas didapatkan bahwa sebagian besar responden penelitian angka kenaikan berat badan saat masa pandemi COVID19 pada mahasiswa angkatan 2017 Fakultas Kedokteran Universitas Malahayati tahun 2020 adalah IMT

Obesitas 2 sebanyak 14 responden $(15,9 \%)$ dan paling sedikit adalah IMT Overweight sebanyak 7 responden $(27,3 \%)$. Karakteristik pola makan dalam penelitian ini dapat dilihat pada tabel 6 berikut:

Tabel 6. Distribusi Frekuensi Berdasarkan Pola Makan

\begin{tabular}{ccc}
\hline Pola Makan & Frekuensi & Persentase (\%) \\
\hline Tidak terdapat perubahan pola makan & 17 & 38,6 \\
Terdapat perubahan pola makan & 27 & 61,4 \\
\hline Jumlah & $\mathbf{4 4}$ & $\mathbf{1 0 0}$ \\
\hline
\end{tabular}

Berdasarkan tabel 6 diketahui pola makan pada responden penelitian angka kenaikan berat badan saat masa pandemi COVID-19 pada mahasiswa angkatan 2017 Fakultas Kedokteran Universitas Malahayati tahun 2020 menunjukkan bahwa sebagian besar responden memiliki perubahan pola makan paling banyak yaitu sebesar 27 $(61 \%)$ dan paling sedikit $17(38,6 \%)$ pada peserta yang tidak terdapat perubahan pola makan. Karakteristik kuesioner pola makan dalam penelitian ini dapat dilihat pada tabel 7 berikut: 
Tabel 7. Distribusi Frekuensi Kuesioner Pola Makan

\begin{tabular}{|c|c|c|c|}
\hline No & Pertanyaan & $\mathbf{N}$ & $\%$ \\
\hline 1 & $\begin{array}{l}\text { Saya sering mengkonsumsi cemilan } \\
\text { selama berada di rumah saat pandemi }\end{array}$ & 39 & 88,6 \\
\hline 2 & $\begin{array}{l}\text { Saya sering menyimpan makanan di } \\
\text { rumah untuk dimakan di waktu senggang } \\
\text { saat pandemi }\end{array}$ & 34 & 77,3 \\
\hline 3 & $\begin{array}{l}\text { Saya sering mengkonsumsi cemilan } \\
\text { setelah mengkonsumsi makanan selama } \\
\text { berada di rumah saat pandemi }\end{array}$ & 33 & 75,0 \\
\hline 4 & $\begin{array}{l}\text { Saya sering merasa lapar selama berada di } \\
\text { rumah saat pandemi }\end{array}$ & 31 & 70,5 \\
\hline 5 & $\begin{array}{l}\text { Nafsu makan saya meningkat ketika } \\
\text { merasa bosan selama berada di rumah } \\
\text { saat pandemi }\end{array}$ & 31 & 70,5 \\
\hline 6 & $\begin{array}{l}\text { Perasaan bosan selama berada di rumah } \\
\text { saat pandemi, membuat saya merasa } \\
\text { cepat lapar sebelum jam makan }\end{array}$ & 30 & 68,2 \\
\hline 7 & $\begin{array}{l}\text { Saya sering mengkonsumsi makanan } \\
\text { manis selama berada di rumah saat } \\
\text { pandemi }\end{array}$ & 29 & 65,9 \\
\hline 8 & $\begin{array}{l}\text { Saya sering mengkonsumsi gorengan } \\
\text { (kentang goreng, nugget goreng, bakso } \\
\text { goreng dsb) selama berada di rumah saat } \\
\text { pandemi }\end{array}$ & 29 & 65,9 \\
\hline 9 & $\begin{array}{l}\text { Saya sering menonton drama/film sambil } \\
\text { makan cemilan selama berada di rumah } \\
\text { saat pandemi }\end{array}$ & 27 & 61,4 \\
\hline 10 & $\begin{array}{l}\text { Saya sering mengkonsumsi cemilan pada } \\
\text { malam hari selama berada di rumah saat } \\
\text { pandemi }\end{array}$ & 25 & 56,8 \\
\hline
\end{tabular}

Berdasarkan tabel 7 diketahui dari 44 pertanyaan kuesioner terdapat 10 pertanyaan yang paling banyak dialami oleh responden penelitian ini, yaitu "Saya sering mengkonsumsi cemilan selama berada di rumah saat pandemi" dengan responden menjawab "iya" $39 \quad(88,6)$ responden dan responden menjawab "tidak" $5(11,4)$ responden, "Saya sering menyimpan makanan di rumah untuk dimakan di waktu senggang saat pandemi" dengan responden menjawab "iya" $34(77,3)$ responden dan responden menjawab "tidak" $10(22,7)$ responden, "Saya sering mengkonsumsi cemilan setelah mengkonsumsi makanan selama berada di rumah saat pandemi" dengan responden menjawab "iya" $33(75,0)$ responden dan responden menjawab "tidak" $11(25,0)$ responden, "Saya sering merasa lapar selama berada di rumah saat pandemi" dengan responden menjawab "iya" $31(70,5)$ responden dan responden menjawab "tidak" 13 $(29,5)$ responden, "Nafsu makan saya meningkat ketika merasa bosan selama berada di rumah saat pandemi" dengan responden menjawab "iya" $31 \quad(70,5)$ responden dan responden menjawab 'tidak" $13(29,5)$ responden, "Perasaan bosan selama berada di rumah saat pandemi, membuat saya merasa cepat lapar sebelum jam makan" dengan responden menjawab "iya" $30(68,2)$ responden dan responden menjawab "tidak" $14(31,8)$ responden, "Saya sering mengkonsumsi makanan manis selama berada di rumah saat pandemi" dengan responden menjawab "iya" 29 $(65,9)$ responden dan responden menjawab "tidak" $15(34,1)$ responden, "Saya sering mengkonsumsi gorengan (kentang goreng, nugget goreng, bakso 
goreng dsb) selama berada di rumah saat pandemi" dengan responden menjawab "iya" $29(65,9)$ responden dan responden menjawab "tidak" 15 $(34,1)$ responden, "Saya sering menonton drama/film sambil makan cemilan selama berada di rumah saat pandemi" dengan responden menjawab "iya" $27 \quad(61,4)$ responden dan responden menjawab "tidak" $17(38,6)$ responden, "Saya sering mengkonsumsi cemilan pada malam hari selama berada di rumah saat pandemi" dengan responden menjawab "iya" $25(56,8)$ responden dan responden menjawab "tidak" $19(43,2)$ responden.

\section{PEMBAHASAN}

\section{Berat Badan}

Berdasarkan data frekuensi distribusi menunjukkan bahwa dari 44 responden terdapat $13(29,5 \%)$ responden dengan berat badan turun $6(13,5 \%)$ responden dengan berat badan tetap dan $25 \quad(56,8 \%)$ responden dengan berat badan naik.

Hasil penelitian menunjukkan bahwasanya perubahan berat badan paling banyak yang dialami responden saat masa pandemi COVID-19 pada mahasiswa angkatan 2017 adalah berat badan naik yang terdiri dari 25 responden $(56,8 \%)$, responden paling sedikit adalah berat badan tetap yang terdiri dari 6 responden $(13,6 \%)$. Hal ini terjadi dikarenakan faktor lingkungan saat masa pandemi COVID-19 yang mengharuskan responden membatasi kegiatan di luar ruangan sehingga hal tersebut memicu rasa bosan yang mengakibatkan lebih banyak mengkonsumsi makanan baik makanan pokok maupun cemilan.

Hasil penelitian ini sesuai dengan penelitian Zachary et al tahun 2020 yang menjelaskan bahwa Sembilan puluh satu persen dari sampel menyatakan bahwa mereka menghabiskan waktu lebih banyak dirumah sekarang daripada sebelum COVID-19. Dua puluh dua persen dari sampel menyatakan bahwa berat badan mereka bertambah 5-10 pon $(2,5-5 \mathrm{~kg})$ (Zachary et al, 2020).

\section{Usia}

Distribusi frekuensi responden berdasarkan umur dapat diketahui yaitu usia 20 tahun 5 responden $(11,4 \%)$, usia 21 tahun 20 responden $(45,5)$, usia 22 tahun 13 responden $(29,5 \%)$ usia 23 tahun 3 responden $(6,8 \%)$, usia 24 tahun 2 responden $(4,5 \%)$ sedangkan usia 25 tahun 1 responden $(2,3 \%)$.

Hasil penelitian menunjukkan bahwasanya usia paling banyak responden yang mengalami kenaikan berat badan saat masa pandemi COVID-19 pada mahasiswa angkatan 2017 adalah usia 21 tahun yang terdiri dari 20 responden $(45,5 \%)$, responden paling sedikit adalah usia 25 tahun yang terdiri dari 1 responden $(2,3 \%)$. Hal ini terjadi dikarenakan faktor usia saat masuk di Fakultas Kedokteran Universitas Malahayati, dimana mayoritas mahasiswa angkatan 2017 berusia 17 tahun.

Hasil penelitian belum sesuai dengan teori yang menyatakan ketika usia bertambah tubuh mengalami penurunan fungsi sehingga aktivitas tubuh juga menurun. Penurunan aktivitas ini menyebabkan terjadinya ketidakseimbangan antara asupan kalori dengan penggunaan kalori saat beraktivitas (Hermawan et al, 2020). Karena pada responden dengan usia 25 tersebut didapatkan bahwa responden telah melakukan diet untuk menurunkan berat badan sebelum pengambilan data penelitian ini.

Penelitian ini sejalan dengan penelitian yang dilakukan oleh Kristiana pada tahun 2020 yang berjudul "Hubungan Antara Pola Tidur Dan Kebiasaan Makan Junk Food Dengan Kejadian Obesitas Pada Mahasiswa Universitas Malahayati Tahun 2019" diketahui rentang usia mahasiswa terbanyak adalah 21 tahun sampai dengan 22 tahun. Usia merupakan salah satu faktor yang berpengaruh terhadap berat badan (Kristiana et al, 2020). 


\section{Jenis kelamin}

Distribusi frekuensi karakteristik berdasarkan jenis kelamin pada penelitian ini didapatkan hasil pada responden berjenis kelamin perempuan sebanyak 27 responden $(61,4 \%)$ dan berjenis kelamin lakilaki sebanyak 12 responden (38,6\%). Hal ini bisa disebabkan oleh faktor jumlah masuknya mahasiswa di Fakultas Kedokteran Universitas Malahayati pada tahun 2017 lebih banyak perempuan dibandingkan dengan laki-laki.

Hasil penelitian ini sesuai dengan teori bahwa beberapa hasil survei kesehatan membuktikan bahwa angka kejadian obesitas lebih banyak dialami oleh perempuan daripada laki laki. Hal ini dikaitkan dengan faktor hormonal yang ada di dalam tubuh perempuan. Hormon yang paling dominan mempengaruhi tubuh perempuan adalah estrogen dan progesterone. Estrogen akan menyebabkan tubuh perempuan lebih cenderung menyimpan lemak dan air sedangkan pada laki laki hormon testosterone lebih cenderung menyebabkan tubuh disusun oleh protein (Hermawan et al, 2020).

Penelitian ini sejalan dengan penelitian sebelumnya yang dilakukan oleh Kristiana pada tahun 2020 yang berjudul "Hubungan Antara Pola Tidur Dan Kebiasaan Makan Junk Food Dengan Kejadian Obesitas Pada Mahasiswa Universitas Malahayati Tahun 2019" yang menyebutkan bahwa perempuan lebih mudah mengalami penambahan berat badan dibandingkan dengan laki-laki (Kristiana et al, 2020).

\section{IMT}

Distribusi frekuensi karakteristik berdasarkan IMT pada penelitian ini didapatkan responden dengan IMT Normal sebanyak $11 \quad(25,0)$ responden, IMT overweight sebanyak $7(15,9)$ responden, IMT obesitas 1 sebanyak $12(27,3)$ responden dan IMT obesitas 2 sebanyak $14(31,8)$ responden IMT responden berbedabeda bisa disebabkan karena tinggi badan dan berat badan dari responden berbeda-beda.

Penelitian ini tidak sejalan dengan penelitian sebelumnya yang dilakukan oleh Kristiana pada tahun 2020 yang berjudul "Hubungan Antara Pola Tidur Dan Kebiasaan Makan Junk Food Dengan Kejadian Obesitas Pada Mahasiswa Universitas Malahayati Tahun 2019" yang menyatakan bahwa sebanyak 30 orang dengan kejadian obesitas $(50 \%)$ dan sebanyak 30 orang tidak obesitas (50\%) (Kristiana et al, 2020). Hal ini disebabkan karena waktu pengukuran IMT dilakukan sebelum masa stay at home saat pandemi COVID-19 sedangkan pengukuran IMT pada penelitian ini dilakukan saat stay at home masa pandemi COVID-19.

\section{Pola Makan}

Berdasarkan data yang diperoleh dari responden kuesioner pola makan menunjukkan bahwa dari 44 responden terdapat $27 \quad(61,4 \%)$ peserta mengalami perubahan pola makan, sedangkan $17 \quad(38,6 \%)$ peserta tidak mengalami perubahan pola makan.

Hasil penelitian menunjukkan bahwasanya pola makan paling banyak yang dialami responden saat masa pandemi COVID-19 Pada Mahasiswa angkatan 2017 adalah terjadi perubahan pola makan yang terdiri dari 27 responden $(61,4 \%)$, responden paling sedikit adalah tidak terdapat perubahan pola makan yang terdiri dari 17 responden (38,6\%). $\mathrm{Hal}$ ini terjadi dikarenakan saat masa pandemi COVID-19 responden lebih banyak menghabiskan waktu dirumah sehingga terjadi perubahan pola makan seperti lebih sering mengkonsumsi cemilan.

Hasil penelitian ini sesuai dengan penelitian Zachary et al tahun 2020 yang menjelaskan bahwa hampir seluruh sampel penelitian menghabiskan lebih banyak waktu dirumah sekarang dibandingkan dengan pra pandemi, $20 \%$ dari sampel mengalami peningkatan berat 
badan sebanyak 5-10 pon dan perilaku makan meningkat selama karantina di rumah (Zachary et al, 2020)

\section{KESIMPULAN}

Terdapat kenaikan berat badan saat masa pandemi COVID-19 pada mahasiswa angkatan 2017 Fakultas Kedokteran Universitas Malahayati Tahun 2020 dengan angka kenaikan berat badan terbanyak $1 \mathrm{Kg}$.

\section{SARAN}

1. Bagi institusi sebagai bahan masukan untuk Universitas Malahayati mengenai pentingnya menanggulangi kenaikan berat badan saat masa pandemi dapat dilakukan proses seminar terkait bahaya Overweight dan Obesitas untuk menambah pengetahuan mahasiswa.

2. Bagi mahasiswa agar dapat memperbaiki pola makan.

3. Bagi peneliti selanjutnya yang tertarik untuk meneliti angka kenaikan berat badan saat masa pandemi COVID-19 disarankan untuk meneliti aktivitas fisik juga agar dapat membandingkan antara angka kenaikan berat badan dengan faktor risiko lain seperti aktivitas fisik saat pandemi COVID-19.

\section{DAFTAR PUSTAKA}

Anggraeni, A. C. (2012). Asuhan Gizi Nutritional Care Process. Yogyakarta: Graha IImu.

Ganong, W.F. (2005). Buku Ajar Fisiologi Kedokteran. Jakarta: EGC.

Hermawan, D., Muhani, N., Sari, N., Arisandi, S., Widodo, S., Lubis, M.Y., et al. (2020). Mengenal Obesitas. Yogyakarta: Penerbit Andi.

Kamus Besar Bahasa Indonesia (KBBI). (2020). Pandemi. https://kbbi.web.id/pandemi.

Kristiana, T., Hermawan, D., Febriani, U., Farich, A. (2020). Hubungan Antara Pola Tidur Dan Kebiasaan Makan Junk Food Dengan Kejadian Obesitas Pada Mahasiswa Universitas Malahayati Tahun 2019. Jurnal Human Care. 5(3): 750-761.
Risnawati, A. (2020). Efektifitas Kebijakan Pembahasan Social Berskala Besar Dalam Masa Pandemi Corona Virus 2019 Oleh Pemerintah Sesuai Amanat UUD NRI Tahun 1945. Jurnal Administrative Law \& Governance 3(2):241.

Zachary, Z., Brianna, F., Brianna L., Garrett, P., Jade, W., Alyssa, D., Mikayla., K. (2020). Self -quarantine and weight gain related risk factors during the COVID-19 pandemic. Elsevier Public Health Emergency Collection 14 (3): 210-216. 